\author{
Стасюкова К.В. \\ старший викладач \\ кафедра обліку та аудиту \\ Одеська національна академія харчових технологій \\ вул. Канатна, 112, м. Одеса, Україна, 65039 \\ E-mail: katerina.stas@mail.ru
}

\title{
ПРОБЛЕМИ ОРГАНІЗАЦІЇ БУХГАЛТЕРСЬКОГО ОБЛІКУ НА ПІДПРИЄМСТВАХ МАЛОГО БІЗНЕСУ
}

Надана характеристика підприємств малого та середнього бізнесу, представлені їх класифікаційні ознаки. Систематизовано основні фрактори впливу на ведення бухгалтерського обліку на малих підприємствах. Виділено основні проблеми та напрями удосконалення і організації обліку на підприємствах малого бізнесу.

Ключові слова: малі підприємства; бухгалтерський облік; податковий облік; особливості організації; фрактори впливу.

This work is licensed under a Creative Commons Attribution 4.0 International License http://creativecommons.org/licenses/by/4.0/

Постановка проблеми та їі зв'язок з важливими науковими та практичними завданнями. Багатоаспектний характер надаваних суб'єктами малого бізнесу послуг веде до необхідності комплексного підходу до проблем формування відповідних систем обліку, звітності, оподаткування.

Проблеми вдосконалення економічного механізму господарювання малого та середнього бізнесу, підвищення ефективності функціонування обліку суб'єктів малого та середнього бізнесу вивчаються в країнах з розвиненою ринковою економікою. Але їх розробки і рекомендації прийнятні для малого і середнього бізнесу розвинених країн, які успішно функціонують в ринкових умовах, в той час як облік малого бізнесу України має невеликий досвід розвитку в умовах ринкової економіки.

В даний час ринкові відносини стрімко розвиваються, в зв'язку з цим виникає необхідність приймати своєчасні управлінські рішення, для чого потрібна правдива i точна інформація, яку можна отримати, маючи добре налагоджений бухгалтерський облік. Для успішної діяльності малих підприємств дуже важливо сформувати ефективну облікову систему, причому обмеженість фінансових і трудових ресурсів визначає специфіку побудови і роботи бухгалтерської служби організації, а також визначає форму ведення обліку, яка залежить від застосовуваної системи оподаткування [1].

Аналіз останніх досліджень та публікацій дає змогу прийти до висновку, що поза увагою науковців залишаються проблеми та особливості обліку на малих підприємствах.

Формулювання цілей дослідження. Основна задача дослідження заключається в розробці рекомендацій для вдосконалення організації обліку на малих підприємствах в існуючих умовах ринкової економіки.

Виклад основних результатів та їх обгрунтування. Для розвитку та сталого функціонування малого бізнесу необхідні чіткі і прості у використанні і розумінні схеми обліку, які стануть для керівництва основою стабільного функціонування. Для цього необхідно сформувати єдину обліково-інформаційну систему, що включає в себе бухгалтерський, податковий облік, а також дані оперативно-технічного обліку, що відображають об'єктивну інформацію. Для малого бізнесу також характерна мінімізація витрат на управління, можливість ведення спрощеної системи податкового, фінансового та статистичного обліку.

На практиці в розвинених країнах малі підприємства мають цілий ряд переваг:

1) при зміні кон'юнктури ринку можуть швидко і гнучко реагувати і приймати управлінські рішення;

2) враховують місцеву специфіку ведення бізнесу в конкретному регіоні;

3) використовують пільгове оподаткування, різні програми державної підтримки;

4) здатність маневрувати при сезонних коливаннях і різних змінах умов;

5) можуть швидко впроваджувати інноваційні ідеї та застосування передового досвіду.

Останнім часом змін зазнає діюча система бухгалтерського обліку підприємств нашої країни. Це призводить до того, що більше уваги приділяється обліку потреб і вимог різних видів підприємств. Це виправдано, адже досвід і деякі нормативні документи показують, що в діяльності малого, середнього і великого підприємництва $є$ цілий ряд особливостей. Це стосується, в першу чергу, питань формування 
облікової політики, вибору форм бухгалтерського обліку та порядку формування звітності. На особливу увагу заслуговують питання організації податкових розрахунків в рамках бухгалтерського обліку, яки включають організацію обліку в умовах загальної та спрощеної системи оподаткування.

Поняття «мале підприємство» в Україні є загальновідомим відповідно до п. 7 ст. 63 Господарського кодексу України малими визнаються підприємства, в яких середньооблікова чисельність працюючих за звітний (фінансовий) рік не перевищує 50 осіб, а обсяг валового доходу від реалізації продукції (робіт, послуг) за цей період не перевищує сімдесят мільйонів гривень [5].

Аналогічні критерії щодо визначення малих підприємств містяться і в ст. 1 чинного Закону України «Про державну підтримку малого підприємництва» [3].

Серед багатьох існуючих факторів, яки відображаються на організації бухгалтерського обліку малих підприємств, більшість вчених-економістів, виділяють наступні:

1. Обмежені фінансові можливості щодо залучення висококваліфікованих фахівців з бухгалтерського обліку і з інших сфер (зокрема, юриспруденції, маркетингу, менеджменту). Тут важливо знати і розуміти, що первинна постановка обліку - така ж необхідна умова при організації підприємства, як і упорядкування його установчих документів.

2. Потреба у всебічних знаннях законодавства для здійснення своєї діяльності. Для організації навіть невеликого підприємства необхідно всебічне знання існуючої законодавчої бази: цивільного, податкового, трудового, валютного, митного, зовнішньоекономічного законодавства. Відсутність відповідних знань часто використовується протилежною стороною в своїх інтересах. Недостатність правової освіти та відсутність знань 3 організації документообігу $є$ сьогодні одними з найбільш актуальних проблем.

3. Невелика кількість працюючих. Оскільки обсяги діяльності не дозволяють зайняти весь робочий час співробітника виконанням виключно його спеціальних обов'язків, його просять також виконувати інші роботи, в тому числі ті, які потребують знань з інших галузей, фахівців з яких у підприємства немає. Таким чином, малі підприємства в більшому ступені потребують універсальних працівників.

4. Слабка захищеність перед податковими та іншими контролюючими органами. Відсутність можливості тримати висококваліфікованих фахівців і недосконалість існуючої судової системи призводить до того, що перевіряючий орган може здійснювати протиправні дії, змушуючи переплачувати податки, робити інші дії, які принижують персонал і інтереси суб'єктів малого підприємництва.

5. Недостатнє знання керівництвом завдань бухгалтерського обліку. В системі управління організацією бухгалтерський облік виконує функцію зворотного зв'язку, тобто надає інформацію керівнику про те, чим він керує і до яких наслідків це призводить. Двома найважливішими завданнями бухгалтерського обліку є забезпечення збереження майна та визначення результатів діяльності. Незнання цих завдань керівництвом призводить іноді до небажаних ситуацій [4].

За умов наявної соціально-економічної кризи, що має місце в Україні визначальну роль малого бізнесу можна охарактеризувати наступними рисами:

- значний сектор економіки;

- свобода ринкового вибору;

- формування конкурентного середовища;

- залучення до легальної економічної сфери

коштів, що перебувають поза банківською сферою економіки;

- основа дрібнотоварного виробництва;

- швидка окупність витрат;

- реалізація інновацій;

- створення робочих місць без будь-якого

фінансування з боку держави;

- розширення самозайнятості населення;

- основа формування середнього класу.

Відповідно до Закону України «Про розвиток та державну підтримку малого і середнього підприємництва в Україні» № 4618-VI від 22 березня 2012 року, суб'єктами малого підприємництва є:

- фізичні особи, зареєстровані в установленому законом порядку як фізичні особи - підприємці, у яких середня кількість працівників за звітний період (календарний рік) не перевищує 50 осіб та річний дохід від будь-якої діяльності не перевищує суму, еквівалентну 10 мільйонам євро, визначену за середньорічним курсом Національного банку України;

- юридичні особи - суб'єкти господарювання будь-якої організаційно-правової форми та форми власності, у яких середня кількість працівників за звітний період (календарний рік) не перевищує 50 осіб та річний дохід від будь-якої діяльності не перевищує суму, еквівалентну 10 мільйонам євро, визначену за середньорічним курсом Національного банку України.

Організація обліку на малому підприємстві, як і на будь якому іншому, вимагає налагодження чіткої системи бухгалтерського обліку, контролю і звітності. Проте малі форми господарювання обумовлюють і ряд специфічних особливостей у застосуванні методів та прийомів бухгалтерського обліку.

Як відомо, починаючи з 01.01.2000 р. всім підприємствам, незалежно від їх організаційноправової форми і форми власності, у тому числі і малим, необхідно вести бухгалтерський облік і складати фінансову звітність згідно Закону України «Про бухгалтерський облік і фінансову звітність в Україні» № 996-XIV від 16.07.99 р. [1]. Цей Закон визначає правові принципи регулювання, організації, ведення бухгалтерського обліку і складання фінансової звітності в Україні.

Отже, з 2000 року суб'єкти малого підприємництва ведуть бухгалтерський (фінансовий) облік відповідно до вимог Закону № 996 в такому обсязі і аналітиці, які будуть достатні для складання фінансової звітності. 
Регістри бухгалтерського обліку мають складатись малим підприємством щомісяця. Підставою для записів у регістрах $є$ первинні документи. Господарські операції заносяться до регістру бухгалтерського обліку за той місяць, у якому вони відбулися. Методичні рекомендації передбачають два варіанти ведення регістрів: проста форма обліку, спрощена форма бухгалтерського обліку. Проста форма бухгалтерського обліку передбачає використання Журналу обліку господарських операцій. Дана форма обліку застосовується підприємствами з незначним документооборотом (кількістю господарських операцій). Спрощена форма бухгалтерського обліку, що рекомендовано для малих підприємств з більшим обсягом документообороту (а отже, і чисельністю працюючих, і обсягом реалізації), з виробництвом готової продукції, виконанням матеріаломістких робіт та послуг, передбачає використання п'яти відомостей та оборотно-сальдової відомості.

Для організації обліку важливе значення має систематизація господарських операцій.

Змінний характер кругообігу засобів у виробничо-фінансовій діяльності малих підприємств діалектичний процес, який визначає їх динамічні, кількісні і якісні зміни на кожний даний момент відліку часу.

Фіксувати і відображати ці зміни за кожним видом засобів і предметів праці в системі бухгалтерського обліку і звітності можна лише за допомогою такого механізму, який не тільки був би достатньо оперативним щодо кількісних переміщень засобів у процесі їх кругообігу, але і адекватним стосовно якісних трансформацій у результаті виробничої діяльності. Саме цим вимогам, 3 певними застереженнями, відповідає план рахунків бухгалтерського обліку, на яких відображаються господарські засоби підприємств і джерела їх утворення.

Будь-який масив інформації для цілісного іiі сприйняття необхідно систематизувати. Тому рахунки бухгалтерського обліку класифікують, тобто систематизують за певними однорідними ознаками. Обидві основні ознаки, за якими класифікують рахунки: за економічним змістом та за призначенням i структурою - $є$ дуже важливими для облікового забезпечення звітності малих підприємств.

Таким чином, врахування зазначених чинників $є$ необхідною умовою вирішення існуючих сьогодні проблем. Особливо це потрібно враховувати при розгляді питань максимального спрощення процедур ведення бухгалтерського обліку малими підприємствами з збереженням тих завдань, які повинен виконувати облік на підприємстві.

Висновки та перспективи подальших досліджень. Підприємства малого бізнесу динамічно розвиваються, адаптуючись до зовнішніх умов і нововведень. Грамотний, чіткий і вдумливий підхід до організації бухгалтерського обліку в організаціях, які є суб'єктами малого підприємництва, може забезпечити досить відчутне зниження трудомісткості облікових процесів, підвищення точності і оперативності обробки бухгалтерської інформації і, отже, підвищення якості прийнятих управлінських рішень.

Подальшого дослідження та вдосконалення потребує: нормативна та правова база забезпечення обліку; розробка методики обліку на малому підприємстві $з$ урахуванням специфіки його функціонуванНя.

\section{Література}

1. Закон України «Про бухгалтерський облік та фінансову звітність в Україні» від 16.07.1999p. № 996-XIV: станом на 02 червня 2016 p. [Електронний ресурс]. - Режим доступу: http://zakon5.rada.gov.ua/laws/show/996-14

2. Закон України «Про державну підтримку та розвиток малого і середнього підприємництва в Україні» від 22.03 .2012 р. № 4618 -VI: станом на 21 січня 2016р. [Електронний ресурс]. - Режим доступу: http://zakon4.rada.gov.ua/laws/show/4618-17

3. Господарський кодекс України / Кодекс України від 16.01.2003 року № 436-IV [зі змін. та доп.]: станом на 02 червня 2016p. [Електронний ресурс]. - Режим доступу: http://zakon3.rada.gov.ua/laws/show/436-15

4. Айзатова М. Ф. Особливості організації обліку на малих підприємствах в умовах адаптації до змін законодавства / М.Ф.Айзатова, Л. М.Макарова // Молодий вчений. - 2014. - №5. - С. 237-240.

5. Бабич В. В. Бухгалтерський облік на підприємствах малого бізнесу в Україні / В. В. Бабич, С. І. Свідерський. - К.: Лібра, 2006. - 160 с.

6. Новодворский В.Д. Бухгалтерский учет на малых предприятиях: [учеб.] / В.Д.Новодворский, Р.Л.Сабанин. - М.: Проспект, 2006. - 296 с.

7. Стасюкова К.В. Облікова система підприємств малого бізнесу із застосуванням спрощеного плану рахунків / К.В. Стасюкова // Науково-методичні аспекти обліково-аналітичної системи підприємства: [монографія] / [В.В. Немченко, Ф.А. Трішин, Л.В. Іванченкова, Н.М. Купріна, Г.О. Ткачук та ін.] ; за заг. ред. д.е.н., проф. В.В. Немченко. - Одеса: Фенікс, 2016. - С. 96-113.

8. Хоча Н.В. Спрощена система обліку та звітності малих підприємств: проблеми трактування і регулювання / Н.В. Хоча // Обліково-аналітичне забезпечення системи менеджменту підприємства : наук.-практ. конф., 26-28 квіт. 2012 р. : тези допов. - Львів: Львівська політехніка, 2012. - С. 337-340.

Стаття надійшла 8.08.2016 Стаття прийнята до друку 22.08.2016 Доступно в мережі Internet 30.09.2016 


\author{
Стасюкова Е.В. \\ старший преподаватель \\ кафедра учета и аудита \\ Одесская национальная академия пищевых технологий \\ ул. Канатная, 112, г. Одеса, Украина, 65039 \\ E-mail: katerina.stas@mail.ru
}

\title{
ПРОБЛЕМЫ ОРГАНИЗАЦИИ БУХГАЛТЕРСКОГО УЧЕТА НА ПРЕДПРИЯТИЯХ МАЛОГО БИЗНЕСА
}

Развитие современной экономики невозможно без активной политики поддержки малого бизнеса. Организация учета на малом предприятии, как и на любом другом, требует налаживания четкой системы бухгалтерского учета, контроля и отчетности. Однако малые формы хозяйствования обусловливают и ряд специфических особенностей в применении методов и приемов бухгалтерского учета. Основные проблемы налогового и бухгалтерского учета в субъектах малого предпринимательства Украины связаны с существующими противоречиями в налоговом законодательстве и его нестабильностью. А также построение и ведение бухгалтерского учета рассматривается предпринимателями как инструмент для исчисления налоговых обязательств. Данная статья посвящена вопросам, связанным с созданием устойчивого конкурентного преимущества малых предприятий на основе организации единой системы бухгалтерского и налогового учета. Для этого необходимо разработать предложения по совершенствованию упрощенных способов ведения учета для субъектов малого предпринимательства. При этом совершенствование учета субъектами малого предпринимательства должно быть основано на грамотном сочетании интересов государства и малого бизнеса.

В статье рассмотрены концепция организации учета в связи со спецификой малых предприятий. Дана характеристика предприятий малого и среднего бизнеса, представлены их классификационные признаки. Систематизированы основные факторы влияния на ведение бухгалтерского учета на малых предприятиях. Выделены основные проблемы и направления совершенствования и организации учета на предприятиях малого бизнеса.

Автором сделан вывод, что предприятия малого бизнеса динамично развиваются, адаптируясь к внешним условиям и нововведениям. Грамотный, четкий и вдумчивый подход к организации бухгалтерского учета в организациях, являющихся субъектами малого предпринимательства, может обеспечить довольно ощутимое снижение трудоемкости учетных процессов, повышение точности и оперативности обработки бухгалтерской информации и, следовательно, повышения качества принимаемых управленческих решений.

Дальнейшего исследования и усовершенствования требует: нормативная и правовая база обеспечения учета; разработка методики учета на малом предприятии с учетом специфики его функционирования.

Ключевые слова: малые предприятия; бухгалтерский учет; налоговый учет; особенности организации; фракторы влияния.

\author{
Stasiukova K. \\ Assistant \\ Department of Accounting and Auditing \\ Odessa National Academy of Food Technologies \\ Kanatna str., 112, Odessa, Ukraine, 65039 \\ E-mail: katerina.stas@mail.ru
}

\section{PROBLEMS OF ACCOUNTING AT SMALL BUSINESS ENTERPRISES}

The development of a modern economy is not possible without the active support of small business policy. Organization of the account in a small business, like any other, requires the establishment of a clear system of accounting, control and reporting. However, small forms of management are responsible for a number of specific features in the application of methods and accounting methods. The main problem of tax and accounting subjects of small business in Ukraine related to the existing contradictions in the tax legislation and its instability. As well as the construction and maintenance of accounting records is 
considered by entrepreneurs as a tool for calculating the tax liability. This article focuses on issues related to the creation of sustainable competitive advantage of small businesses on the basis of organization of the accounting and tax accounting system. To do this, you must develop proposals for improving the simplified methods of accounting for small businesses. At the same time improving the accounting by small businesses it must be based on a proper combination of interests of the state and small businesses.

The article describes the concept of the organization of accounting in connection with the specifics of small businesses. The characteristics of small and medium-sized businesses are represented by their classification features. Systematized the main factors of influence on accounting in small enterprises. The main problems and ways of improving the organization and accounting for small businesses.

The author concludes that small businesses are developing dynamically, adapting to external conditions and innovations. Competent, clear and thoughtful approach to the organization of accounting in organizations which are small businesses, can provide quite a sizeable decline in the complexity of accounting processes, improve the accuracy and efficiency of processing accounting information and, consequently, improve the quality of management decisions.

Further research and improvements required: normative and legal base of mainstreaming; Development of accounting methods a small business considering the specifics of its functioning.

Keywords: small businesses; accounting; tax accounting; characteristics of the organization; influence factors.

\section{References}

1. Zakon Ukrainy «Pro bukhhalterskyi oblik ta finansovu zvitnist v Ukraini» vid 16.07.1999r. № 996-KhIV: Stanom na 02 chervnia 2016 r. (2016). Retrieved 2016, from http://zakon5.rada.gov.ua/laws/show/996-14

2. Zakon Ukrainy «Pro rozvytok ta derzhavnu pidtrymku maloho i serednoho pidpryiemnytstva v Ukrai-ni» tanom na 21 sichnia 2016r. (2016). Retrieved 2016, from http://zakon4.rada.gov.ua/laws/show/4618-17

3. Hospodarskyi kodeks Ukrainy / Kodeks Ukrainy vid 16.01.2003 roku № 436-IV [zi zmin. ta dop.]: Stanom na 02 chervnia 2016r. (2016). Retrieved from http://zakon3.rada.gov.ua/laws/show/436-15

4. Aizatova, M. F., \& Makarova, L. M. (2014). Osoblyvosti orhanizatsii obliku na malykh pidpryiemstvakh v umovakh adaptatsii do zmin zakonodavstva / M.F.Aizatova,. Molodyi Vchenyi, 5, 237-240.

5. Babych, V. V., \& Sviderskyi, I. I. (2006). Bukhhalterskyi oblik na pidpryiemstvakh maloho biznesu v Ukraini. K.: Libra.

6. Novodvorskyi,, V. D., \& Sabanyn, R. L. (2006). Bukhhalterskyi uchet na malıkh predpryiatyiakh. M.: Prospekt.

7. Stasiukova, K. V., Nemchenko, V. V., Trishyn, F. A., \& Ivanchenkova, N.M. Kuprina, H.O. Tkachuk, L. V. (2016). Oblikova systema pidpryiemstv maloho biznesu iz zastosuvanniam sproshchenoho planu rakhunkiv. Naukovo-metodychni Aspekty Oblikovo-analitychnoi Systemy Pidpryiemstva, 96-113.

8. Khocha, N. V. (2012). Sproshchena systema obliku ta zvitnosti malykh pidpryiemstv: Problemy traktuvannia i rehuliuvannia. Oblikovo-analitychne Zabezpechennia Systemy Menedzhmentu Pidpryiemstva : Nauk.-prakt. Konf., 26-28 Kvit. 2012 R., 337-340. 